\title{
KVALITATÍVNA ANALÝZA PREŽÍVANIA POKRAČUJÚCICH VÄZIEB K ZOSNULÉMU PARTNEROVI U ŽIEN V OBDOBÍ STAROBY
}

\author{
Miriam Masaryková, Lucia Záhorcová
}

\begin{abstract}
Abstrakt
Primárnym ciel’om výskumnej štúdie bola kvalitatívna analýza pokračujúcich väzieb u žien po strate partnera. Ďalšími ciel'mi bola analýza kvality vzt’ahu s partnerom pred stratou a analýza rituálov využívaných po strate. Výskumný súbor tvorilo 10 žien po strate partnera v období neskorej dospelosti až staroby. Vek participantiek sa pohyboval v rozmedzí od 56 do 83 rokov $(M=71,4$ rokov; $S D=3,07)$, dížka vzt'ahu s partnerom sa pohybovala od 32 do 59 rokov $(M=46,9$ rokov; $S D=8,6)$ a uplynulý čas od straty partnera sa pohyboval v rozmedzí od 9 mesiacov do 10 rokov, 4 mesiacov $(M=47,5$ mesiaca; $S D=11,26)$. Údaje boli získané pološtrukturovanými rozhovormi, ktorých ciel'om bolo hlbšie preskúmanie preživania ovdovených participantiek. Na analýzu dát bola použitá metóda konsenzuálneho kvalitatívneho výskumu. Výsledkom analýzy údajov boli 3 domény: Formy pokračujúcich väzieb u vdov po strate partnera, Formy rituálov u vdov po strate partnera, Pozitívne a negatívne vnímané aspekty kvality vzt’ahu. Na základe získaných dát bol popísaný typický prípad prežívania väzieb k partnerovi u ovdovených žien. Formy pokračujúcich väzieb sú rôznorodé, môžu mat' charakter pozitívnych, ambivalentných, ale aj negatívne prežívaných väzieb. Môžu byt' pokračovaním rôznych aspektov vzt’ahu, ktorý existoval pred stratou, pričom ponúkajú nové možnosti, ktorými sa vzt'ah môže menit' alebo napredovat'. Výsledky sú interpretované a diskutované s predchádzajúcimi výskumnými zisteniami.
\end{abstract}

Kl'účové slová: vdovstvo, strata partnera, pokračujúce väzby, kvalita vzt’ahu, kvalitatívna analýza

\section{QUALITATIVE ANALYSIS OF CONTINUING BONDS AFTER THE LOSS OF A PARTNER IN ELDERLY WIDOWS}

\begin{abstract}
The primary aim of this research study was a qualitative analysis of continuing bonds in women after the loss of a partner. The sub-goals were to analyse the quality of the pre-death relationship with a partner and to analyse the rituals used during the grieving process. The research sample consisted of 10 elderly widows. Age of participants ranged from 56 to 83 years $(M=71,4$ years; $S D=3,07)$, length of the relationship with a partner ranged from 32 to 59 years $(M=46,9$ years; $S D=8,6)$ and time elapsed since the loss ranged from 9 months to 10 years, 4 months $(M=47,5$ months; $S D=11,26)$. Data were obtained by semi-structured interviews, aimed to explore more in-depth experiences of widowed participants. Consensual Qualitative Research was used to analyse the data. The data analysis resulted in 3 domains: Forms of continuing bonds in widows after the loss of a partner, Forms of rituals in widows after the loss of a partner, Positively and negatively perceived aspects of the relationship quality. Based on the obtained data, the typical case of experiencing continuing bonds to a partner in widowed women was described. The forms of continuing bonds are diverse, they can be experienced positively, ambivalently, or negatively. They may mean a continuation of various aspects of the pre-loss relationship, offering new opportunities for the relationship to change or progress after death. The results are interpreted and discussed in line with previous research findings.
\end{abstract}

Keywords: widowhood, loss of a partner, continuing bonds, quality of relationship, qualitative analysis

Došlo: 18. 12. 2019

Schváleno: 17. 10. 2020 


\section{Úvod}

Strata blízkeho človeka je ranou, ktorá vždy výrazne zasiahne prežívanie pozostalej osoby a v dôsledku ktorej sa musí pozostalý začat' orientovat' vo svete bez milovaného človeka. O to horšie je stratit' životného partnera, s ktorým človeka spájali roky spolužitia, spoločne strávených chvíl' a spomienok. Podl’a Špatenkovej (2005) prináša ovdovenie radikálnu zmenu životného spôsobu, často aj sociálneho postavenia, životnej úrovne, prestíže, obmedzenie sociálnych kontaktov a nutnost' socializácie $\mathrm{v}$ novej životnej roli - roli vdovy a vdovca. V rámci transformačného procesu po strate sa mení vzt’ah smútiaceho k zosnulému na taký, ktorý môže fungovat' aj po strate (Boerner \& Heckhausen, 2003). Navyše, pre starších l'udí, ktorí so svojím partnerom prežili desiatky rokov, môže byt' často nemožné, aby nepokračovali v blízkom emocionálnom vzt’ahu so zosnulým partnerom (Costello \& Kendrick, 2000). V tejto súvislosti sa v literatúre hovorí o pokračujúcich väzbách po strate, ktoré Klass, Silverman a Nickman (1996) definovali ako určitú vnútornú reprezentáciu zosnulého, ktorá je bežnou súčast'ou procesu smútenia. Field, Gal-Oz a Bonanno (2003) týmto názvom označujú prítomnost' pokračujúceho vnútorného vzt'ahu so zosnulým človekom. Zahraniční autori navyše popisujú rôzne formy prežívania pokračujúcich väzieb, napríklad identifikáciu so zosnulým, sny, rozprávanie sa so zosnulým, halucinácie, zážitky prítomnosti zosnulého, spomienky na minulé udalosti, využivanie hmotných objektov, či rituály (Hayes \& Leudar, 2016; Rando, in Reisman, 2001; Vale-Taylor, 2009). Vzhl'adom na nedostatok kvalitatívnych zahraničných štúdií a úplnú absenciu domácich výskumov týkajúcich sa tejto problematiky je naším primárnym ciel'om urobit' analýzu pokračujúcich väzieb po smrti partnera na výskumnom súbore ovdovených žien. Predpokladáme, že ženy sú viac zdiel'ne a tiež ochotnejšie popísat' svoje prežívanie týkajúce sa tejto citlivej témy. V tejto súvislosti sme odvodili prvú výskumnú otázku:

\section{O1: Aké sú formy preživania pokračujúceho vzt'ahu u vdov po strate partnera?}

Rituály majú špecifické postavenie v našej spoločnosti, sú však aj dôležitou súčast'ou smútenia po strate blízkej osoby. V súčasnosti sa vel'mi zdôrazňuje osobný zmysel rituálu pre jednotlivca, ked’že smútiaci môžu vykonávat' ten istý typ rituálu, ale z rôznych dôvodov, a zároveň každý rituál môže mat' pre nich rôzny zmysel (Root \& Exline, 2014; Vale-Taylor, 2009). Podl'a výskumných zistení môžu mat' rituály charakter pokračujúceho vzt'ahu (Barnhill, 2011; Romanoff \& Terenzio, 1998; Vale-Taylor, 2009), prípadne môžu byt' len činmi vykonanými z rešpektu či povinnosti (Vale-Taylor, 2009). Navyše, prístup k smrti, spôsoby smútenia, ale aj využívanie rituálov sú značne ovplyvnené kultúrnym pozadím (Bäckström, 2019). Vzhl’adom na nedostatok domácich a novších zahraničných výskumných štúdií, ktoré by sa venovali problematike rituálov u smútiacich, sme sa rozhodli zvolit' druhý výskumný ciel', ktorým je urobit' analýzu využivania rituálov u žien po strate partnera so zameraním na osobný zmysel rituálu pre jednotlivca. V súlade s naším výskumným ciel'om sme určili druhú výskumnú otázku:

\section{O2: Aké rituály využivajú ovdovené ženy po strate partnera?}

Kvalita vzt'ahu medzi smútiacim a zosnulým pred stratou do určitej miery súvisí s kvalitou vzt’ahu, ktorý pokračuje po strate. Hoci toto tvrdenie zastáva väčšina autorov (Boerner \& Heckhausen, 2003; Field, Gal-Oz, \& Bonanno, 2003; Hayes \& Leudar, 2016; Karydi, 2018), vo výsledkoch výskumov nachádzame nejednotné závery. Vo všeobecnosti sa spája väčšia spokojnost' vo vzt’ahu pred stratou s častejším využívaním pokračujúcich väzieb po strate (Field, Gal-Oz, \& Bonanno, 2003). Karydi (2018) navyše spája pozitívny vzt’ah pred stratou s následným pozitívnym prežívaním pokračujúceho vzt'ahu. Rozdiely sa ukazujú v prípade, kedy bol vzt'ah pred stratou blízkeho konfliktný. Zatial' čo Tyson-Rawson (in Steffen \& Coyle, 2011) hovorí o následnom negatívnom prežívaní pokračujúcej väzby, Hayesová 
a Leudar (2016) poukazujú na pozitívne vnímanie pokračujúceho vzt'ahu, vd’aka ktorému dochádza $\mathrm{k}$ vyriešeniu konfliktov $\mathrm{z}$ minulosti. V dostupnej literatúre navyše chýba väčší vhl'ad do problematiky transformácie vzt'ahu pred stratou na pokračujúci vzt'ah po strate. Preto sme si za d'alší ciel' zvolili urobit' analýzu kvality vzt'ahu s partnerom u ovdovených žien pred stratou. V súvislosti s naším ciel'om si kladieme tretiu výskumnú otázku:

O3: Aká bola kvalita vzt’ahu s partnerom pred stratou u ovdovených žien?

\section{Metóda}

\section{Výskumný súbor}

Podmienkami pre výber účastníčok do výskumu bol status vdovy, vek vyšší ako 55 rokov, ked’že sa zaujímame o populáciu v období neskorej dospelosti až staroby, a minimálny čas od straty pol roka, aby účast' vo výskume v krátkom čase od straty nepôsobila na vdovy traumatizujúco. Pre získanie účastníčok do výskumu bol zvolený príležitostný výber vzorky, pre ktorý sme sa rozhodli vzhl'adom na citlivý charakter skúmanej témy. Výsledný výskumný súbor tvorilo 10 ovdovených žien. Vek účastníčok sa pohyboval v rozmedzí od 56 do 83 rokov $(M=71,4$ rokov; $S D=3,07)$, dížka vzt'ahu s partnerom sa pohybovala od 32 do 59 rokov $(M=46,9$ rokov; $S D=8,6)$ a uplynulý čas od straty partnera sa pohyboval v rozmedzí od 9 mesiacov do 10 rokov, 4 mesiacov $(M=47,5$ mesiaca; $S D=11,26)$. U troch ovdovených žien išlo o stratu očakávanú, predovšetkým následkom dlhodobejšieho pôsobenia rakoviny, u šiestich účastníčok išlo o stratu náhlu, napr. v dôsledku infarktu a u jednej účastníčky išlo o násilnú stratu, konkrétne suicídium $\mathrm{v}$ dôsledku diagnostikovania nevyliečitel'ného ochorenia.

\section{Metódy zberu a analýzy údajov}

Telefonicky alebo osobne sme oslovili 13 ovdovených žien s prosbou o účast' vo výskume. Potenciálnym účastníčkam bol vysvetlený zámer a priebeh výskumu ešte pred vyslovením súhlasu alebo nesúhlasu z ich strany. Výsledný výskumný súbor tvorilo 10 participantiek, s ktorými sme sa dohodli na čase a mieste rozhovoru. Rozhovory sa konali prevažne v domácnostiach participantiek. Účastníčky sme pred realizáciou samotného rozhovoru informovali o cieli nášho výskumu, anonymite získaných údajov, nahrávaní rozhovoru na záznamník, využití zozbieraných dát, možnosti kedykol'vek ukončit' účast' vo výskume, prípadne neodpovedat' na niektoré otázky. Následne participantky podpísali informovaný súhlas. Rozhovory boli realizované prvou autorkou štúdie. Tá sa najskôr pokúsila o vytvorenie príjemnej a bezpečnej atmosféry, prípadne zodpovedala otázky, ktoré účastníčky zaujímali. Následne kládla hlavné otázky a v prípade potreby kládla doplňujúce otázky. Rozhovory trvali od 35 minút do 2 hodín, priemerne 50 minút.

Zber údajov sme realizovali prostredníctvom pološtrukturovaného rozhovoru. Účastníčkam sme kládli nasledujúce hlavné otázky: Aký bol Váš vzt’ah s partnerom pred stratou? Zmenil sa Váš vzt’ah po strate? Akým spôsobom si zachovávate (pokračujúci) vzt'ah s partnerom po strate? Aké rituály ste využívali alebo využívate po strate? Ako sa zmenili spôsoby udržiavania pokračujúceho vzt’ahu v čase? Ako ste pokračujúce väzby vnímali?

$\mathrm{Na}$ analýzu údajov sme použili konsenzuálny kvalitatívny výskum (Consensual Qualitative Research, CQR, Hill et al., 2005). CQR sa spolieha na opis fenoménov prostredníctvom slov miesto čísel a uprednostňuje malý počet prípadov, ktoré sú však skúmané intenzívne (Hill, Thompson \& Williams, 1997). Odporúčaná vel'kost' výskumného súboru je 8-15 participantov. Pre lepšie objasnenie problematiky odporúčajú Hillová, 
Thompsonová a Williamsová (1997) popísanie typického prípadu, ktorý reprezentuje prežívanie charakteristické pre väčšinu participantov. Pre získanie čo najobjektívnejších výsledkov si CQR vyžaduje spoluprácu tímu, najmenej dvoch výskumníkov, ktorí analyzujú dáta osobitne a následne sa snažia dospiet' ku konsenzu prostredníctvom otvoreného dialógu (Hill, Thompson, \& Williams, 1997). V našom prípade to boli dve študentky psychológie a jedna auditorka práce, vysokoškolská pedagogička so skúsenost’ami v kvalitatívnom výskume, ktorá poskytovala spätnú väzbu k analyzovaným dátam.

Po ukončení zberu dát prvá autorka práce všetky nahrávky doslovne prepísala. Pre zachovanie anonymity bol každej účastníčke pridelený kód a boli odstránené všetky osobné a citlivé údaje. Autorka v rozhovoroch označila dlhšie pauzy, prípadne plač. Pred začatím analýzy boli rozhovory rozdelené na polovicu, pričom každá členka tímu analyzovala samostatne najprv prvú a potom druhú polovicu. Prvým krokom analýzy bolo vytvorenie domén, teda hlavných spoločných tém rozhovorov. Následne boli rozdel'ované základné myšlienky z jednotlivých rozhovorov do už vzniknutých domén. Posledným krokom bola krížová analýza, kedy každý člen tímu samostatne zarad'oval hlavné myšlienky do kategórií a podkategórií. Po každom kroku sa výskumníci stretli, aby o výsledkoch diskutovali a dospeli ku konsenzu ohl'adom kategórií, podkategórií a reprezentatívneho výroku. Výsledný konsenzus bol odovzdaný auditorke na kontrolu a následne boli zapracované jej pripomienky do výsledkov. Na záver bola vytvorená typológia kategórií a podkategórií podla Hillovej, Thompsonovej a Williamsovej (1997), ktoré ich odporúčajú rozdelit' na všeobecné (týkajúce sa všetkých participantov), typické (týkajúce sa aspoň polovice prípadov) a variabilné (týkajúce sa najmenej dvoch, ale menej ako polovice prípadov). Typológiu kategórií a podkategórií možno nájst' $v$ tabul'kách 1,2 a 3.

\section{Výsledky}

V rámci prvej výskumnej otázky sme sa zamerali na popísanie foriem pokračujúcich väzieb, ktoré si vdovy po strate partnera zachovávajú. Odvodili sme doménu s názvom Formy pokračujúcich väzieb u vdov po strate partnera (tabul'ka č. 1). Zistili sme, že ani u jednej ovdovenej ženy sa neobjavila len jedna forma pokračujúcich väzieb, ale hned' niekol'ko a v rôznej intenzite využívania. Výsledky poukazujú na rozmanitost' týchto foriem, ktorými si vdovy pokračujúce väzby po strate zachovávajú. Tomu nasvedčuje aj fakt, že sa nám ukázala iba jedna kategória ako všeobecná (charakteristická pre všetky prípady), a to konkrétne spomínanie na zosnulého partnera. Participantky sa vyjadrovali, že po takom dlhom čase spolunažívania je prirodzené, že na partnera čas od času v myšlienkach spomínajú. Druhou najčastejšou formou pokračujúcich väzieb boli sny. V rámci tejto kategórie štyri participantky popisovali pravidelné snenie o zosnulom, tri uvádzali absenciu snov a jedna príliš časté snenie. Absencia snov bola u všetkých účastníčok spájaná s prianím, aby sa im o partnerovi snívalo, a to najmä tesne po strate (napr. „Ale dlho sa mi nesnívalo...tak som chcela, že by sa mi o ňom snívalo“). Jedna vdova, ktorej sa o partnerovi snívalo každý večer, prežívala ambivalentné pocity, ktoré na jednej strane pramenili z radosti, lebo sny boli príjemné, na druhej strane vyvolávali dojem, akoby spolu s partnerom nad'alej žili, čo bolo pre ňu nepríjemné.

Jedinou typickou kategóriou, ktorú sme odvodili, boli zážitky pritomnosti zosnulého, ktoré uvádzalo pät' účastníčok. Špecifickost' tejto kategórie vidíme v rôznych formách, v ktorých sa zážitky objavujú. Tri účastníčky opisovali duševný pocit, že je partner stále s nimi, prípadne že ich ochraňuje a pomáha im, u jednej vdovy sa objavili vizuálne zážitky prítomnosti partnera (,Raz som takto sedela $\mathrm{v}$ tejto fotelke a to bolo jedenkrát, bol za dverami, stál...som ho videla, ako stojí."), dve účastníčky popisovali jeho prítomnost' 
napríklad prostredníctvom pohybu určitého predmetu $(,, \ldots$ no a ked' sme sa obliekali, tak zrazu to autíčko sa pohlo...“), nezvyčajných zvukov v domácnosti alebo symbolicky (,,...pozriem sa a je presne 12 hodín, tak že aha - to mi on dáva znamenie.“). Charakter týchto zážitkov vnímali všetky účastníčky pozitívne, pocit’ovali komfort pri predstave, že je partner s nimi. Za dôležitú kategóriu, ktorá sa ukázala u štyroch ovdovených žien, považujeme rozprávanie sa so zosnulým. Participantky najčastejšie popisovali dialóg s partnerom, v ktorom sa mu vyrozprávajú, s partnerom sa radia, prípadne ohlásia, pokial' niekam odchádzajú. Tri účastníčky explicitne vyjadrili, že im takýto dialóg vel'mi pomáha a zachovávajú ho aj po dlhšom čase od straty (napr. ,...pomáha mi to vel'mi, pretože mi tak odl'ahne na duši, hej, že prídem, že sa mu vyrozprávam...").

Výsledky ukazujú, že u každej participantky v rámci nášho výskumného súboru boli prítomné aspoň nejaké formy pokračujúcich väzieb, ale nemuselo vždy íst' o aktívne udržiavanie vzt'ahu s partnerom. Aktívne udržiavanie vzt'ahu, ktoré explicitne popisovali štyri participantky, sa obvykle spájalo s počiatočnými problémami s akceptáciou straty a práve $\mathrm{s}$ reorganizáciou vzt'ahu s partnerom a nájdením spôsobov, akými môže vzt’ah pokračovat' aj po strate. Štyri účastníčky explicitne opisovali, ako sa zachovávanie vzt’ahu s partnerom postupne stalo súčast'ou ich d'alšieho života, čo považovali za spôsob, ktorý im napomáha v d’alšom fungovaní. Jedna účastníčka špecificky vyjadrila: „A je to krásne, že človek má takú predstavu, že žije s ním d'alej...a ved' on je tu. Jeho telo tam zakopali, ale jeho duša, jeho dobré srdiečko je tu." Pokračujúce väzby sa prejavovali aj v podobe rozprávania o zosnulom $s$ rodinou, čo považovali vdovy za spôsob, akým je zosnulý stále medzi nimi prítomný, alebo $\mathrm{v}$ podobe snahy o splnenie manželovho priania.

V rámci niektorých foriem pokračujúcich väzieb sme zaregistrovali negatívne prežívanie. Konkrétne túženie po zosnulom, ktoré sa objavilo u jednej účastníčky tesne po náhlej strate partnera, bolo charakterizované želaním, aby sa zosnulý nejakým spôsobom vrátil, čo bolo sprevádzané vyjednávaním s Bohom, rumináciou a neschopnost'ou akceptovat' situáciu. Zároveň táto účastníčka vyjadrila, že až ked' našla spôsob, ktorým si mohla zachovat' pokračujúci vzt’ah s partnerom, dokázala stratu viac akceptovat'. Ako sama povedala: „,..tým, že som si tak našla ho tu...v tých bežných veciach a že stále sa s ním rozprávam, radím sa s ním, ked' niečo neviem....". V tejto súvislosti sa prejavil tiež pokračujúci interpersonálny konflikt, neodpustenie, čo participantka opísala ako neschopnost' partnerovi odpustit' veci, ktorými ju zranil a ponížil, pričom zdôraznila, že ,to už do konca života asi bude. To už ináč nebude“. 
Tabul'ka č. 1: Doména 1 - Formy pokračujúcich väzieb u vdov po strate partnera

\begin{tabular}{|c|c|c|c|c|}
\hline & Kategórie & Podkategórie & Výrok & $\boldsymbol{K}$ \\
\hline \multirow{11}{*}{ 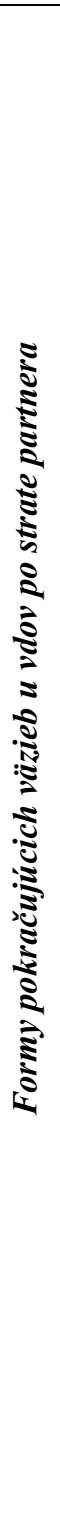 } & $\begin{array}{l}\text { Spomínanie } \\
\text { na zosnulého } \\
\text { partnera } 10 / 10\end{array}$ & & „Spomínam naňho stále...“ & $\check{\mathbf{S}}$ \\
\hline & Sny & $\begin{array}{l}\text { pravidelné snenie } \\
4 / 10\end{array}$ & $\begin{array}{l}\text { „teraz sa mi viacej sníva, už sa mi aj minulý } \\
\text { týždeň, aj teraz sa mi..." }\end{array}$ & $\mathbf{R}$ \\
\hline & & $\begin{array}{l}\text { absencia snov } \\
3 / 10\end{array}$ & $\begin{array}{l}\text { „Ale dlho sa mi nesnívalo...tak som chcela, že } \\
\text { by sa mi o ňom snívalo, ked' zomrel a nesnívalo sa } \\
\text { mi..“ }\end{array}$ & $\mathbf{R}$ \\
\hline & & $\begin{array}{l}\text { príliš časté snenie } \\
1 / 10\end{array}$ & $\begin{array}{l}\text { „Hned' po smrti sa mi snívalo každý večer. To } \\
\text { bolo niečo...ako mňa to síce po jednej stránke tak tešilo, } \\
\text { lebo tie sny boli aj príjemné, ale také, také, že } \\
\text { normálne, že akoby sme d'alej žili spolu ten život..."“ }\end{array}$ & \\
\hline & $\begin{array}{l}\text { Zážitky } \\
\text { prítomnosti } \\
\text { zosnulého 5/10 }\end{array}$ & & $\begin{array}{l}\text { „Raz som takto sedela v tejto fotelke a to bolo } \\
\text { jedenkrát, bol za dverami, stál, som ho videla ako stojí. } \\
\text { Takú károvanú košel’u mal..." }\end{array}$ & \\
\hline & $\begin{array}{l}\text { Rozprávanie sa } \\
\text { so zosnulým 4/10 }\end{array}$ & & $\begin{array}{l}\text { „....aj ked' idem preč, tak mu poviem, kde idem, } \\
\text { potom ked' som niekde dlho, tak sa mu } \\
\text { ospravedlňujem, že ma tam zdržali...ale mi to pomáha, } \\
\text { pomáha mi to. Urozprávam sa tam s ním.“. }\end{array}$ & $\mathbf{R}$ \\
\hline & $\begin{array}{l}\text { Reorganizácia } \\
\text { vzt’ahu } \\
\text { s partnerom } 4 / 10\end{array}$ & & $\begin{array}{l}\text {,...je to krásne, že človek má takú predstavu, že } \\
\text { žije s ním d'alej....a ved' on je tu. Jeho telo tam zakopali, } \\
\text { ale jeho duša, jeho dobré srdiečko je tu.“ }\end{array}$ & $\mathbf{R}$ \\
\hline & $\begin{array}{l}\text { Rozprávanie } \\
\text { o zosnulom } \\
\text { S rodinou } 2 / 10\end{array}$ & & $\begin{array}{l}\text { „Spomínam naňho stále, pri každej tejto, či } \\
\text { niekde idem, či ho spomínam, medzi súrodencami } \\
\text { alebo medzi rodinou..." }\end{array}$ & $\mathbf{R}$ \\
\hline & $\begin{array}{l}\text { Túženie } \\
\text { po zosnulom 1/10 }\end{array}$ & & $\begin{array}{l}\text { „Mne sa o ňom absolútne nesnívalo. A ja som z } \\
\text { toho začala byt' chorá. Si hovorím, preboha, to prečo? } \\
\text { Prečo aspoň nepríde mi povedat' niečo, toto neni } \\
\text { možné, aby sa nemohol nejako uvol'nit'..." }\end{array}$ & \\
\hline & $\begin{array}{l}\text { Splnenie } \\
\text { partnerovho } \\
\text { priania } 1 / 10\end{array}$ & & $\begin{array}{l}\text {,...tak som mu ja dala, takému chlapcovi tuto } \\
\text { vedl'a u susedov urobit' takýto krížiček, ale je } \\
\text { drevený....a splnila som mu jeho prianie...“ }\end{array}$ & \\
\hline & $\begin{array}{l}\text { Pokračujúci } \\
\text { interpersonálny } \\
\text { konflikt, } \\
\text { neodpustenie } 1 / 10\end{array}$ & & $\begin{array}{l}\text { „A mám to } \mathrm{v} \text { tom srdci ešte doteraz, takže ja } \\
\text { som mu ani neodpustila...som taká zatvrdnutá v tom a } \\
\text { nemôžem sa z toho ako vymotat'..." }\end{array}$ & \\
\hline
\end{tabular}

Vysvetlivky: $\mathrm{TK}=$ typológia kategórií; $\mathrm{VS}=$ všeobecné; $\mathrm{T}=$ typické; $\mathrm{VR}=$ variabilné

V rámci druhej výskumnej otázky sme sa sústredili na analýzu rituálov, ktoré ovdovené ženy po strate využívajú. Odvodili sme doménu Formy rituálov u vdov po strate partnera (tabul'ka č. 2). Rituály sa v nejakej forme objavili u všetkých participantiek, pričom najpočetnejšou kategóriou u deviatich účastníčok bola návšteva cintorína. Frekvencia navštevovania sa však odlišovala, niektoré účastníčky hovorili, že najviac navštevovali cintorín tesne po strate, pričom postupne chodili menej, jedna účastníčka naopak zdôrazňovala, že aj po skoro dvoch rokoch od straty chodí každý deň. Pre niektoré ženy má najväčší význam návšteva cintorína na partnerove narodeniny, meniny či výročie úmrtia a vel'mi často sa tu stretáva celá rodina, aby si zosnulého uctili a pripomenuli spolu. Pre viaceré vdovy je takáto návšteva spojená s rozprávaním sa so zosnulým, či už v duchu alebo 
nahlas. Druhou najpočetnejšou kategóriou je zapálenie sviečky zosnulému, čo opisovalo sedem participantiek. Zistili sme, že ovdovené ženy často využívajú viaceré formy rituálov, a to aj súčasne. Zapálenie sviečky sa najčastejšie spája s návštevou cintorína a pripomenutím si výročí, tri participantky však zdôrazňovali, že partnerovi často zapália sviečku aj doma. Časté bolo tiež pripomenutie si zosnulého v čase výroči, ktoré bolo najčastejšie spojené s rodinným posedením a spoločnou návštevou cintorína.

Ako špecifický rituál sa vyskytlo aj vystavenie fotografie doma, či už spoločnej fotografie alebo fotografie partnera. Zaujímavým rituálom, ktorý sa objavil u štyroch vdov, je modlitba. Účastníčky sa pravidelne modlili za dušu partnera, prípadne považovali modlitbu za prosbu, aby ich partner bol v poriadku, nakol'ko sa báli, čo s ním po smrti kvôli jeho vlastnostiam bude.

U troch ovdovených žien sa objavilo použivanie hmotných objektov po zosnulom. Jedna účastníčka napríklad nosila partnerovu obrúčku, iná, ktorá opisovala vel'mi aktívne udržiavanie pokračujúceho vzt'ahu s partnerom, spomínala hned' viacero predmetov, napríklad partnerov paplón v posteli, či dve košele, ktoré má symbolicky zviazané rukávmi na pre ňu špeciálnom mieste, kde často so zosnulým partnerom vedie aj dialóg. Ovdovené ženy si často spomenú na partnera aj pri používaní bežných predmetov (napr. „Ja čo chytím do ruky, to poviem: „Toto on kúpil, toto on kúpil..."). Dve ženy si tiež ponechali hmotné objekty po zosnulom, napríklad darčeky, ktoré dostali od partnera alebo niektoré jeho veci. U jednej účastníčky sa objavila kategória odpor voči návšteve cintorína, ked’že podl'a jej slov už len pomyslenie, že tam leží, jej nerobí dobre. Cintorín navštevuje len v najnutnejších prípadoch, je to pre ňu skôr istá forma povinnosti. Z výsledkov vyplýva, že žiadna participantka nevyužívala iba rituály, ale vždy boli zároveň prítomné aj iné formy pokračujúcich väzieb.

Tabul'ka č. 2: Doména 2 - Formy rituálov u vdov po strate partnera

\begin{tabular}{|c|c|c|c|}
\hline \multicolumn{2}{|c|}{ Kategórie } & Výrok & \\
\hline \multirow{8}{*}{ 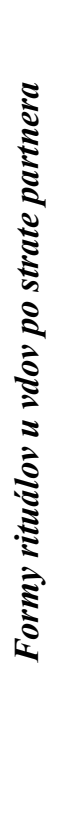 } & Návšteva cintorína 9/10 & $\begin{array}{l}\text { „Aj teraz, ked’ idem na hrob, na cintorín, tak vždy mu } \\
\text { poviem, že mi chýba..."“ }\end{array}$ & \\
\hline & Zapálenie sviečky 7/10 & $\begin{array}{l}\text { „Ale na záhradke, ked’ odchádzam, tak mám tam kahanček } \\
\text { a zasvietim mu sviečku.“ }\end{array}$ & \\
\hline & $\begin{array}{l}\text { Pripomenutie si zosnulého } \\
\text { v čase výročí } 7 / 10\end{array}$ & $\begin{array}{l}\text { „...to zakaždým, ked' má výročie, akože narodenia, výročie } \\
\text { smrti, meniny, tak to vždy celá rodina, ako tu sa naobedujeme a } \\
\text { potom ideme spoločne mu zapálit' na ten hrob tú sviečku.““ }\end{array}$ & \\
\hline & Vystavenie fotografie $6 / 10$ & $\begin{array}{l}\text { „...no a tuto máme fotografiu ked' sme mali } 60 \text { rokov, tak } \\
\text { som to dala tuto...“ }\end{array}$ & \\
\hline & Modlitba 4/10 & $\begin{array}{l}\text { „....každý deň ho mám na ume, každý deň, lebo sa modlím } \\
\text { zaňho, za jeho dušu...“ }\end{array}$ & $\mathbf{R}$ \\
\hline & $\begin{array}{l}\text { Používanie hmotných } \\
\text { objektov po zosnulom } \\
\text { 3/10 }\end{array}$ & $\begin{array}{l}\text { „...ja mám obrúčku, po ňom nosím. Moju som ale, ešte ked’ } \\
\text { žil, stratila. A túto som tam v šuflíku našla, tak ju nosím.“ }\end{array}$ & $\mathbf{R}$ \\
\hline & $\begin{array}{l}\text { Ponechávanie si } \\
\text { hmotných objektov po } \\
\text { zosnulom } 2 / 10\end{array}$ & $\begin{array}{l}\text { „...po mužovi ked' mi niečo ostalo, napríklad že mi niečo } \\
\text { dal alebo nejaký darček a ked' to chytím do ruky si spomeniem...““ }\end{array}$ & $\mathbf{R}$ \\
\hline & $\begin{array}{l}\text { Odpor voči návšteve } \\
\text { cintorína } 1 / 10\end{array}$ & $\begin{array}{l}\text { „...nenávidím chodit’ na cintorín, sa mi to protiví. Mne je } \\
\text { tam zle, ked' si pomyslím, že tam je a je tam popol..."“ }\end{array}$ & \\
\hline
\end{tabular}

Vysvetlivky: TK= typológia kategórií; $\mathrm{VS}=$ všeobecné; $\mathrm{T}=$ typické; $\mathrm{VR}=$ variabilné 
V rámci tretej výskumnej otázky sme sa zamerali na analýzu kvality vzt’ahu s partnerom pred stratou. Vzhl'adom na jedinečnost' a individualitu každého interpersonálneho vzt'ahu sa objavilo množstvo kvalít, ktoré sme popísali v rámci domény Pozitívne a negatívne vnímané aspekty kvality vzt'ahu (tabul'ka č. 3). Pozitívne vnímané aspekty vzt'ahu sa týkali spoločných kvalít vo vzt’ahu, partnerových kvalít a osobného hodnotenia kvality vzt'ahu. Učastníčky v rámci spoločných kvalít vo vzt’ahu vyzdvihovali najmä spoločné trávenie vol’ného času a dlhé trvanie vzt’ahu. Dĺžka vzt’ahu bola pre každú významná z rôznych hl'adísk a najviac ju zdôrazňovali tie, ktoré spolu s partnerom žili viac ako 50 rokov. Jedna zdôrazňovala neschopnost' zabudnút' na partnera a potrebu zachovávania vzt'ahu nad'alej (,,To sa nedá zabudnút'. Ked' niekoho máš rád, 54 rokov s niekým žit', to samo o sebe hovorí. A je to krásne, že človek má takú predstavu, že žije s ním d'alej..."), druhá zase retrospektívne posúdenie ich vzt’ahu ako ideálneho a objavilo sa aj t’ažké zvládanie neočakávaného odchodu partnera. Ako významné kvality sa objavili vzájomná tolerancia, interpersonálna blízkost' s partnerom, vzájomná kompatibilita a schopnost' spoločne zvládnut' konflikty. Podkategórie vzájomné priatel'stvo, vzájomná opora, vzájomná úcta a plány do budúcnosti neboli zdôrazňované tak často, všetky boli zastúpené vždy jednou participantkou. Účastníčky d'alej spomínali partnerove kvality, ktoré vel'mi oceňovali, a to najmä praktickú pomoc od partnera, ale tiež jeho pozitívne vlastnosti, ako nekonfliktnost' a snahu o zmenu svojich chýb. V rámci osobného hodnotenia kvality vzt'ahu tri účastníčky celkovo spomínali celoživotnú spokojnost' so vzt'ahom. Dve účastníčky navyše uviedli, že sa ich vzt'ah s časom zlepšil a vo vzt'ahu bolo významné odpúšt’anie chýb.

V rámci negatívne vnímaných aspektov vzt’ahu tri účastníčky spomínali negatívny vplyv partnerových kamarátov, a to najmä v súvislosti so zneužívaním alkoholu u partnera. V súvislosti s partnerovou osobnost'ou dve účastníčky spomínali partnerovu žiarlivost' a negatívne vlastnosti partnera, ako napr. časté nadávanie. Jedna účastníčka navyše spomínala partnerovu neveru. Niektoré účastníčky uvádzali tiež osobné hodnotenie kvality vztahah, a to v zmysle nespokojnosti so vzt'ahom, tolerancie negativnych aspektov vzt'ahu $(,, \ldots$ musela som to pretrpiet', no, bohužial'."), hnevu na partnera a zhoršenej kvality vzt'ahu (,,..tak po 40-tke to tak začalo, tak akože intenzívne. Už potom ten život bol taký o ničom.“).

V rámci výsledkov sme odvodili tiež typický prípad účastníčky nášho výskumu. Ten predstavuje ovdovená žena, ktorá hodnotí svoj vzt'ah s partnerom pred stratou najmä prostredníctvom pozitívnych kvalít, hoci uvádza, že sa sem-tam objavil aj nejaký konflikt, ked’že žiadne partnerstvo nie je dokonalé. Pozitívne vníma najmä spoločne strávený čas, vzájomnú toleranciu a blízkost' vo vzt’ahu, ktorý pre ňu mnoho znamenal, ked’že s partnerom spolu prežili dlhé roky. Po strate sa pre ňu začína obdobie smútenia, ktoré je typické vynárajúcimi sa otázkami ohl'adom zmyslu straty, procesom postupnej akceptácie straty a zachovávaním pokračujúcich väzieb k partnerovi. Ovdovená žena si na partnera spomína, praje si, aby sa jej o ňom snívalo, vedie s ním dialógy a niekedy zažíva jeho prítomnost', čo jej prináša komfort. Pripomína si ho v čase výročí, návštevou cintorína, zapálením sviečky, vystavenou fotografiou alebo modlitbou. Prostredníctvom osobných rituálov nemizne jej väzba a puto $k$ partnerovi. 
Tabul'ka č. 3: Doména 3 - Pozitívne a negatívne vnímané aspekty kvality vzt’ahu

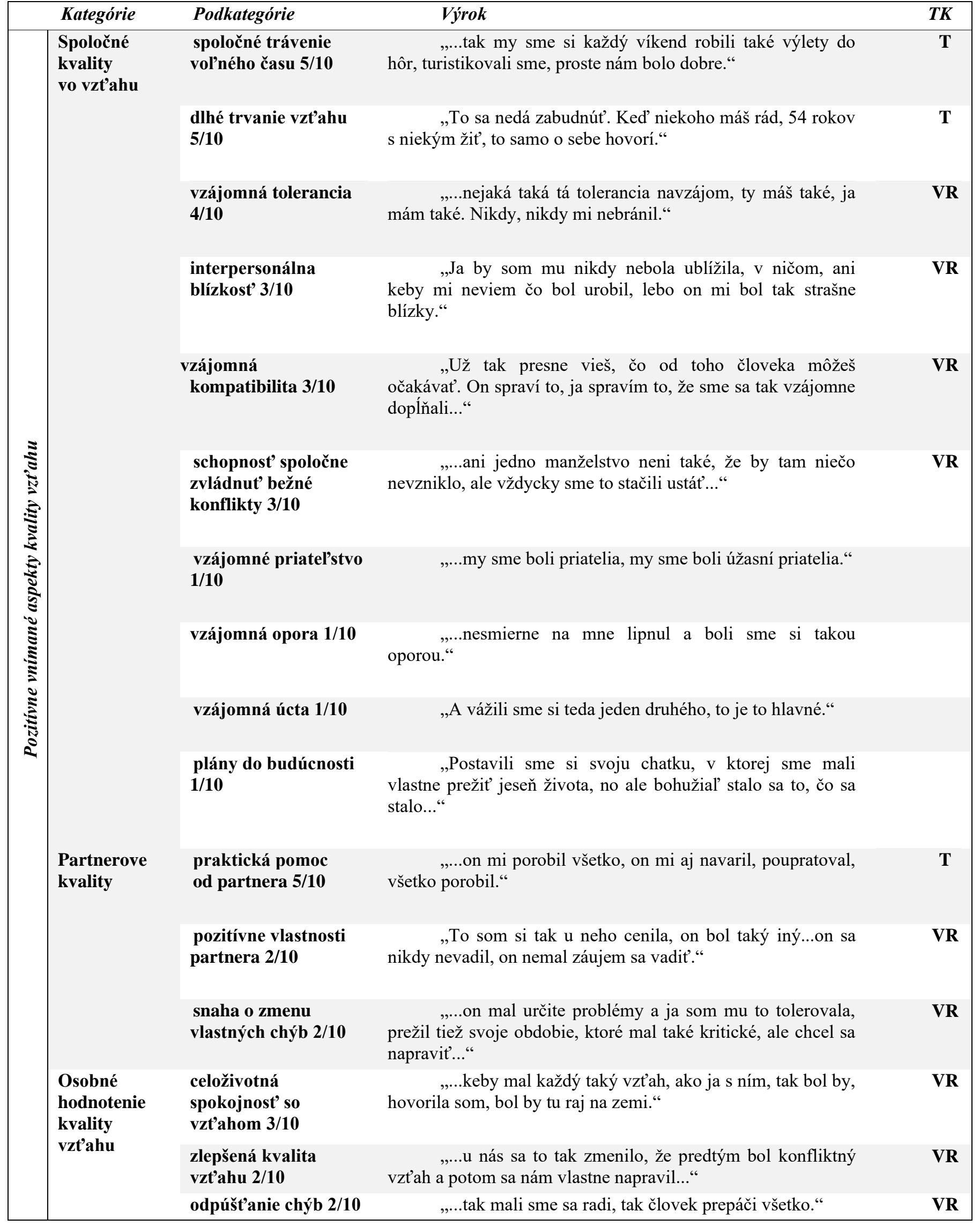




\begin{tabular}{|c|c|c|c|c|}
\hline \multirow{10}{*}{ 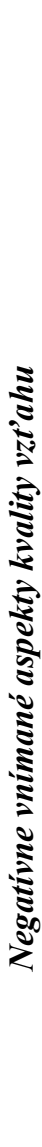 } & $\begin{array}{l}\text { Negatívny } \\
\text { vplyv } \\
\text { partnerových } \\
\text { kamarátov } \\
3 / 10\end{array}$ & & $\begin{array}{l}\text { „...ale potom sa tak pokazil } \mathrm{v} \text { tej robote, tam mal takých } \\
\text { kamarátov, čo ho zviedli } \mathrm{k} \text { tomu pitiu..." }\end{array}$ & VR \\
\hline & $\begin{array}{l}\text { Zneužívanie } \\
\text { alkoholu } \\
\text { u partnera } \\
3 / 10\end{array}$ & & $\begin{array}{l}\text { „...on dost' pil, takže priamo z roboty chodil do krčmy a ja } \\
\text { pre neho zase ked' som išla z roboty..." }\end{array}$ & VR \\
\hline & \multirow[t]{2}{*}{$\begin{array}{l}\text { Partnerova } \\
\text { osobnost' }\end{array}$} & $\begin{array}{l}\text { partnerova žiarlivost' } \\
2 / 10\end{array}$ & $\begin{array}{l}\text { „...on bol vel'mi žiarlivý teda... tá žiarlivost' ho donášala ozaj } \\
\text { k takým zúfalým činom..." }\end{array}$ & VR \\
\hline & & $\begin{array}{l}\text { negatívne vlastnosti } \\
\text { partnera } 2 / 10\end{array}$ & $\begin{array}{l}\text { „Ja som nemala výhradu voči ničomu, len to nadávanie. To } \\
\text { mi strašne vadilo...“ }\end{array}$ & \\
\hline & \multicolumn{2}{|l|}{$\begin{array}{l}\text { Interpersonál } \\
\text { ny konflikt } \\
2 / 10\end{array}$} & $\begin{array}{l}\text { „No on ináč nebol zlý v podstate, no len ked’ bol opitý, kerý } \\
\text { chlap je dobrý. Boli také nezhody..." }\end{array}$ & VR \\
\hline & \multirow{4}{*}{$\begin{array}{l}\text { Osobné } \\
\text { hodnotenie } \\
\text { kvality } \\
\text { vzt'ahu }\end{array}$} & $\begin{array}{l}\text { zhoršená kvalita } \\
\text { vzt’ahu 1/10 }\end{array}$ & $\begin{array}{l}\text { „...tak po } 40 \text {-tke to tak začalo, tak akože intenzívne. Už } \\
\text { potom ten život bol taký o ničom, už som sa chcela aj rozviest' } \\
\text { s ním..." }\end{array}$ & \\
\hline & & $\begin{array}{l}\text { nespokojnost' so } \\
\text { vzt'ahom } 1 / 10\end{array}$ & $\begin{array}{l}\text { „...no to bolo také - také zvlášstne manželstvo. Nebola som } \\
\text { spokojná, no ale čo som mala robit'..." }\end{array}$ & \\
\hline & & $\begin{array}{l}\text { tolerancia negatívnych } \\
\text { aspektov vzt'ahu } 1 / 10\end{array}$ & $\begin{array}{l}\text { „48 rokov sme boli spolu. Že som to vôbec aj } \\
\text { vydržala...musela som to pretrpiet' no, bohužial'.“ }\end{array}$ & \\
\hline & & hnev na partnera $1 / 10$ & $\begin{array}{l}\text { „Ja som už bola naňho strašne nahnevaná, lebo mňa strašne } \\
\text { s tým ranil.““ }\end{array}$ & \\
\hline & $\begin{array}{l}\text { Partnerova } \\
\text { nevera } 1 / 10\end{array}$ & & $\begin{array}{l}\text {,...ale mal aj nejakú babu. Ja som to zistila, no a potom som } \\
\text { už robila riadne poriadky.“ }\end{array}$ & \\
\hline
\end{tabular}

Vysvetlivky: $\mathrm{TK}=$ typológia kategórií; $\mathrm{T}=$ typické; $\mathrm{VR}=$ variabilné

\section{Diskusia}

V súlade s doterajšími výskumnými zisteniami (Epstein, Kalus, \& Berger, 2006; Klass, Silverman, \& Nickman, 1996) sa aj v našom výskume ukázalo, že pokračujúce väzby sa po strate často vyskytujú, čo dokazuje aj fakt, že u každej participantky boli prítomné aspoň nejaké formy väzieb, najčastejšie však viacero simultánne. Zároveň tieto formy, ktoré vdovy využívajú, sú rôznorodé (Field, Gal-Oz, \& Bonanno, 2003; Field \& Filanosky, 2010), čo sa ukázalo aj v našom výskume.

U všetkých účastníčok sa objavilo spomínanie na zosnulého partnera. Pre mnohé je spomínanie prirodzené, nakol'ko s partnerom strávili roky spolužitia, čo je v súlade s tvrdením, že pre niektoré vdovy, ktorých partnerský vzt'ah trval niekol'ko desiatok rokov, môže byt' t'ažké nezachovávat' blízky emocionálny vzt'ah so zosnulým partnerom (Costello \& Kendrick, 2000). Súhlasíme s názorom Ryckebosch-Dayez, Zech, Cord a Taverne (2016), že staršie ovdovené ženy často pocit'ujú samotu, sú viac konfrontované s absenciou partnera, čo môže viest' $\mathrm{k}$ zvýšenému premýšlaniu a spomínaniu na partnera. Jedna vdova v našom výskume špecificky uviedla, že ked’ je sama, viac premýšl’a nad mnohými vecami v súvislosti so zosnulým partnerom.

V rámci nášho výskumu sa však ukázalo, že spomínanie na partnera nebolo u všetkých ovdovených žien spojené s udržiavaním blízkeho emocionálneho pokračujúceho vzt'ahu s partnerom. V niektorých prípadoch ide skôr o zachovanie pamiatky alebo spomienky na zosnulého či spoločný život. Aktívne angažovanie sa $\mathrm{v}$ zachovávaní vzt'ahu explicitne popisovali štyri participantky, ktoré hovorili o rôznych druhoch komunikácie s partnerom. Najčastejšie sa u nich vyskytovalo spomínanie, vedenie dialógu s partnerom, snenie, zážitky 
prítomnosti partnera a rôzne osobné formy rituálov. V počiatočných štádiách smútenia nemusí byt' jednoduché zachovávat' blízky pokračujúci vzt’ah s partnerom. U žien sa po strate vynárali existenciálne otázky a hl'adanie zmyslu straty (Neimeyer, 2011), najčastejšie vyjednávaním s Bohom a procesom osobného utvárania zmyslu straty. Objavili sa aj problémy s akceptáciou straty, napríklad vo forme túženia, aby sa partner vrátil. Preokupácia myšlienkami na zosnulého a vzt’ah s ním je často súčast'ou smútenia a tiež znakom, že smútenie ešte nebolo vyriešené (Rubin, 1984). Nutnost' rekonštrukcie zmyslu je dôležitá pre akceptáciu a integráciu reality straty, fyzickej neprítomnosti zosnulého a reorganizácie vzt'ahu s partnerom po strate - a to najmä v prípade, ked' je strata málo koherentná s predpokladaným svetom jednotlivca (Neimeyer, 2014). Práve nutnost' transformácie a reorganizácie vzt'ahu s partnerom je základom pre udržiavanie emocionálne blízkeho pokračujúceho vzt’ahu, ako sa ukázalo u štyroch účastníčok. Takýto proces zahŕňa dekonštrukciu, ale aj zachovanie niektorých mentálnych reprezentácií zosnulého a zároveň konštrukciu nových (Boerner \& Heckhausen, 2003). Predpokladáme, že nejde o lineárny, ale vel'mi komplexný proces, nakol'ko sme zistili individuálne rozdiely u smútiacich. Napríklad jedna účastníčka spomínala, že akceptovat' realitu straty sa jej podarilo až vtedy, ked' dokázala nájst' spôsoby zachovávania vzt'ahu s partnerom. Ud'alšej vdovy sa objavilo zachovávanie vzt'ahu s partnerom ešte skôr, než bola s realitou straty a statusom vdovy prvýkrát vedome konfrontovaná. Hoci vo Wordenovom modeli smútenia akceptácia straty predchádza nájdeniu trvalého spojenia so zosnulým, sám autor zdôrazňuje flexibilitu v jednotlivých úlohách smútenia (Worden, 2009), pričom niekedy je potrebná opätovná práca s niektorými úlohami alebo práca s viacerými súčasne. V našom výskume sa ukázalo, že jednotlivé úlohy sa môžu počas smútenia aj zamieňat'.

Ako vel'mi častá forma pokračujúcich väzieb sa ukázalo snenie s partnerom. Sny boli často vnímané pozitívne, spojené s interakciou s partnerom (Parkes, 1970), prípadne chápané ako rozlúčka s partnerom (Epstein, Kalus, \& Berger, 2006) či obsahujúce aspekt, ktorý ovdovenej žene napomáhal k akceptácii a zmierneniu negatívnych emócií. Jedna účastníčka uviedla, že jej pomohlo, ked' v snoch videla, že partner nie je utrápený a chápala to tak, že sa má dobre a je v poriadku. Prikláňame sa k názoru, že snívanie o zosnulom môže obsahovat' terapeutickú alebo liečivú kvalitu a slúžit' na zachovanie spojenia so zosnulým počas procesu smútenia, ako to opisujú Wright et al. (2014).

Polovica účastníčok opisovala zážitky pritomnosti partnera, ktoré sa ukázali v rôznych kvalitách. Podl'a Reesa (1971) môže íst' o rôzne zmyslové kvality alebo len o pocit, že je zosnulý prítomný, čo sa ukázalo aj v našom výskume. Ovdovené ženy obvykle prežívali duševné pocity, že je partner s nimi, že im poskytuje ochranu, pomáha im. Hoci sa v literatúre diskutuje o problematickosti týchto zážitkov, ide najmä o typ tzv. externalizovaných pokračujúcich väzieb, teda ilúzií a halucinácií (Field \& Filanosky, 2010). Formou rozhovorov $\mathrm{s}$ účastníčkami by bolo t'ažké objektívne posúdit' mieru ich prispôsobenia sa strate a tiež to, či k nej zážitky prítomnosti napomáhajú. Sústredili sme sa preto viac na vnímanie zážitkov samotnými participantkami, ktoré nám vo všetkých prípadoch potvrdili pocit'ovanie komfortu pri predstave, že je partner pri nich, a to napriek zisteniam Hayesovej a Leudara (2016), že pozostalí nemusia vnímat' zážitky prítomnosti po celý čas pozitívne.

Pokračujúce väzby majú mnoho foriem a podôb, zatial' čo niektoré môžu predstavovat' jednorazový čin (napr. splnenie priania), iné sú zamerané na hodnotenie (minulých udalostí, spomienok; výčitky svedomia), pretrvávajúce pocity a emócie (pocit spolupatričnosti, pokračujúci konflikt, neodpustenie, túženie po zosnulom) či aktívne formy komunikácie s partnerom (rozprávanie sa so zosnulým, zážitky prítomnosti zosnulého). Predpokladáme, že prítomnost' pokračujúcich väzieb u každej participantky by sa dala vysvetlit' tým, že strata 
milovaného človeka vždy zanechá dopad na živote smútiaceho (Vickio, 1999) a špecificky pre ovdovené ženy môže byt' významné zachovávat' symbolický pokračujúci vzt'ah s partnerom po dlhých rokoch vzájomného spolužitia.

Rituály, ktoré ovdovené ženy využívajú, môžu byt' jednoduché (návšteva cintorína) alebo komplexné (Castle \&Phillips, 2003), zahŕňajúce viacero rituálov naraz, napríklad pripomenutie si zosnulého včase výroči s rodinou v rámci spoločného posedenia alebo návštevy cintorína, čo bolo pre ovdovené ženy v našom výskume vel'mi dôležité.

V súlade s doterajšími výskumnými zisteniami sa ukázalo, že rituály využívané po strate sú väčšinou osobne zmysluplné (Castl e\& Phillips, 2003; Vale-Taylor, 2009). S osobným významom rituálov sa pracuje aj v smútkovom poradenstve a terapii, nakol'ko môžu napomáhat' pri riešení komplikovaného zármutku (Sas \& Coman, 2016). Ovdovené ženy, ktoré dávali rituálom osobný význam, ich obvykle chápali ako spôsob, akým si zachovávajú vzt’ah s partnerom. Náš výskum teda potvrdzuje, že prostredníctvom rituálov si vdova môže zachovávat' pokračujúce väzby a emocionálny vzt’ah s partnerom (Barnhill, 2011; Romanoff \& Terenzio, 1998).

Kvalita vzt’ahu sa v našom výskume ukázala ako vel'mi komplikovaný konštrukt, nakol'ko zahŕňa faktory na strane oboch partnerov a môže byt' zároveň obomi partnermi inak vnímaná (Hassebrauck \& Fehr, 2002). Z výsledkov môžeme usudzovat', že ovdovené ženy, ktoré popisovali viac pozitívnych kvalít vzt’ahu z rôznych uhlov pohl'adu, prežívali viac foriem pokračujúcich väzieb s partnerom, než ženy, ktoré sa o kvalite vzt’ahu vyjadrovali všeobecnejšie a uvádzali menej kvalít. Pozitívnejšia mentálna reprezentácia vzt'ahu s partnerom teda pravdepodobne vedie k väčšiemu využívaniu pokračujúcich väzieb (Field, Gal-Oz, \& Bonanno, 2003). Na rozdiel od kvantitatívneho výskumu pokračujúcich väzieb po strate rodiča (Karydi, 2018) sme zistili, že pri väčšom využívaní väzieb nemusí íst' nutne o pozitívne prežívané pokračujúce väzby, ale vyskytujú sa aj ambivalentné (napr. príliš časté snenie) či negatívne preživajúce väzby (napr. výčitky svedomia, pokračujúci konflikt, absencia snov), čo podla nás môže súvisiet' s dížkou času od straty a individuálnost'ou procesu smútenia. Navyše, rozdiely vo výsledkoch môžu byt' zapríčinené odlišným výskumným súborom, ale aj typom výskumu.

Výsledky naznačujú, že pokračujúce väzby obsahujú určité aspekty kvality vzt'ahu pred stratou (Boerner \& Heckhausen, 2003; Hayes \& Leudar, 2016). Môže íst' o pozitívne (napr. interpersonálna blízkost'), ale aj negatívne aspekty vzt'ahu (napr. konflikt), ktorý existoval pred stratou, pričom pokračujúce väzby ponúkajú nové možnosti, ktorými sa vzt’ah môže menit' alebo napredovat' (napríklad prostredníctom dialógu, zážitkov prítomnosti partnera), ako hovoria Hayesová a Leudar (2016).

Hoci sme sa snažili eliminovat' nežiaduce faktory, ktoré by mohli viest' k skresleniu výsledkov a interpretácií, uvedomujeme si, že naša práca má isté limitácie. Výsledky kvalitatívneho typu výskumu nemožno zovšeobecnit' na celú populáciu, ked’že pri kvalitatívnom výskume sa obvykle kladie dôraz na hlbšie preskúmanie fenoménov, nie na vel'kost' výskumného súboru, ktorý je charakteristický nízkym počtom participantov. Ďalšou limitáciou môže byt' príležitostný výber účastníkov, ktorý nezaručuje reprezentatívnost' pre zvolenú populáciu. Participantky si väčšinu informácií vybavovali retrospektívne, pričom vo väčšine prípadov bol uplynulý čas od straty niekol'ko rokov, čím mohlo dôjst' k skresleniu niektorých informácií. Hoci väčšina participantiek zažila stratu partnera v období posledných šiestich rokov, jedna participantka zažila stratu pred desiatimi rokmi, čo môže skresl'ovat' výsledky. Limitujúcim faktorom je tiež nehomogénny typ straty u participantiek, nakol'ko štyri zažili stratu očakávanú v dôsledku choroby partnera, u väčšiny to bola strata náhla. 
Napriek spomenutým limitáciám považujeme našu prácu za prínosnú pre viaceré oblasti psychológie. Ako jediný výskum na tému pokračujúcich väzieb po strate partnera na Slovensku sme priniesli väčší vhl'ad do danej problematiky. Prostredníctvom individuálnych príbehov ovdovených žien sme opísali kvalitu vzt’ahu s partnerom, charakter prežívania pokračujúcich väzieb a využívania rituálov v kontexte tejto náročnej životnej udalosti.

Ďalší výskum by sa mohol zamerat’ na súvislosti pokračujúcich väzieb s adaptáciou na stratu, ako aj na hlbšie porozumenie procesom transformácie vzt'ahu pred stratou na pokračujúce väzby po strate. Zaujímavé by bolo rozšírenie výskumného zamerania na iné typy participantov, napríklad pokračujúce väzby u rodičov po strate diet'at'a alebo u detí po strate rodiča či súrodenca.

\section{Záver}

U ovdovených žien v našom výskume sa ukázalo niekol'ko rôznorodých foriem pokračujúcich väzieb, pričom najčastejšie sa jednalo o spomínanie na zosnulého partnera. Typickými pokračujúcimi väzbami bolo tiež snívanie o zosnulom partnerovi a zážitky prítomnosti zosnulého. Ukázalo sa, že pokračujúce väzby môžu obsahovat' určité aspekty kvality vzt'ahu pred stratou. Môže íst' o pozitívne, ale aj negatívne aspekty vzt'ahu, ktorý existoval pred stratou, pričom pokračujúce väzby ponúkajú nové možnosti, ktorými sa vzt’ah s pozostalým môže transformovat' alebo napredovat'. Ovdovené ženy, ktoré popisovali viac pozitívnych kvalít vzt'ahu s partnerom pred stratou prežívali tiež viac foriem pokračujúcich väzieb s partnerom po strate, v porovnaní so ženami, ktoré sa o kvalite vzt'ahu vyjadrovali všeobecnejšie a uvádzali menej pozitívnych kvalít vzt'ahu. Štúdiou sme sa snažili zdôraznit' individualitu a jedinečnost' každého smútiaceho človeka, čo sa ukázalo prostredníctvom unikátnych životných príbehov s jednotlivými účastníčkami rozhovorov.

\section{Literatúra}

Barnhill, J. J. (2011). Giving Meaning to Grief: The Role of Rituals and Stories in Coping with Sudden Family Loss [Unpublished doctoral dissertation]. University of South Florida.

Bäckström, B. M. G. G. (2019). Death, mourning and post-death rituals of elderly migrants. Mortality, 25(2), 220-231. https://doi.org/10.1080/13576275.2018.1559137

Boerner, K., \& Heckhausen, J. (2003). To have and have not: adaptive bereavement by transforming mental ties to the deceased. Death Studies, 27(3), 199-226. https://doi.org/10.1080/07481180302888

Castle, J., \& Phillips, W. L. (2003). Grief rituals: Aspects that facilitate adjustment to bereavement. Journal of Loss and Trauma, 8(1), 41-71. https://doi.org/10.1080/15325020305876

Costello, J., \& Kendrick, K. (2000). Grief and older people: the making or breaking of emotional bonds following partner loss in later life. Journal of Advanced Nursing, 32(6), 1374-1382. https://doi.org/10.1046/j.1365-2648.2000.01625.x

Epstein, R., Kalus, CH., \& Berger, M. (2006). The continuing bond of the bereaved towards the deceased and adjustment to loss. Mortality, 11(3), 253-269. https://doi.org/10.1080/13576270600774935

Field, N. P., \& Filanosky, C. (2010). Continuing bonds, risk factors for complicated grief, and adjustment to bereavement. Death Studies, 34(1), 1-29.

https://doi.org/10.1080/07481180903372269 
Field, N. P., Gal-Oz, E., \& Bonanno, G. A. (2003). Continuing bonds and adjustment at 5 years after the death of a spouse. Journal of Consulting and Clinical Psychology, 71(1), 110-117. https://doi.org/10.1037/0022-006X.71.1.110

Hassebrauck, M., \& Fehr, B. (2002). Dimensions of relationship quality. Personal Relationships, 9(3), 253-270. https://doi.org/10.1111/1475-6811.00017

Hayes, J., \& Leudar, I. (2016). Experiences of continued presence: On the practical consequences of 'hallucinations' in bereavement. Psychology and Psychotherapy: Theory, Research and Practice, 89(2), 194-210. https://doi.org/10.1111/papt.12067

Hill, C. E., Thompson, B. J., Hess, S. A., Knox, S., Williams, E. N., \& Ladany, N. (2005). Consensual qualitative research: An update. Journal of Counseling Psychology, 52(2), 196-205. https://doi.org/10.1037/0022-0167.52.2.196

Hill, C. E., Thompson, B. J., \&Williams, E. N. (1997). A guide to conducting consensual qualitative research. The Counseling Psychologist, 25(4), 517-572. https://doi.org/10.1177/0011000097254001

Karydi, E. (2018). Childhood bereavement: The role of the surviving parent and the continuing bond with the deceased. Death Studies, 42(7), 412-425. https://doi.org/10.1080/07481187.2017.1363829

Klass, D., Silverman, P. R., \& Nickman, S. L. (1996). Continuing bonds: New understandings of grief. Taylor \& Francis.

Neimeyer, R.A. (2014). The narrative arc of tragic loss: Grief and the reconstruction of meaning. International Journal of Existential Psychology \& Psychotherapy, 5(1), 27-32.

Neimeyer, R. A. (2011). Reconstructing meaning in bereavement. Rivista di psichiatria, 46(56), 332-336. https://doi.org/10.1708/1009.10982

Parkes, C. M. (1970). The first year of bereavement: A longitudinal study of the reaction of London widows to the death of their husbands. Psychiatry, 33(4), 444-467. https://doi.org/10.1080/00332747.1970.11023644

Rees, W. D. (1971). The hallucinations of widowhood. British Medical Journal, 4, 37-41. https://doi.org/10.1136/bmj.4.5778.37

Reisman, A. S. (2001). Death of a spouse: Illusory basic assumptions and continuation of bonds. Death Studies, 25(5), 445-460. https://doi.org/10.1080/07481180126216

Romanoff, B. D., \& Terenzio, M. (1998). Rituals and the grieving process. Death Studies, 22(8), 697-711. https://doi.org/10.1080/074811898201227

Root, B. L., \& Exline, J. J. (2014). The role of continuing bonds in coping with grief: Overview and future directions. Death Studies, 38(1), 1-8. https://doi.org/10.1080/07481187.2012.712608

Rubin, S. S. (1984). Mourning distinct from melancholia: The resolution of bereavement. British Journal of Medical Psychology, 57(4), 339-345. https://doi.org/10.1111/j.20448341.1984.tb02599.x

Ryckebosch-Dayez, A. S., Zech, E., Cord, J. M., \& Taverne, C. (2016). Daily life stressors and coping strategies during widowhood: A diary study after one year of bereavement. Death Studies, 40(8), 461-478. https://doi.org/10.1080/07481187.2016.1177750

Sas, C., \& Coman, A. (2016). Designing personal grief rituals: An analysis of symbolic objects and actions. Death Studies, 40(9), 1-12. https://doi.org/10.1080/07481187.2016.1188868

Steffen, E., \& Coyle, A. (2011). Sense of presence experiences and meaning-making in bereavement: A qualitative analysis. Death Studies, 35(7), 579-609.

https://doi.org/10.1080/07481187.2011.584758

Špatenková, N. (2005). Fenomén vdovství. In D. Sýkorová, D. Šimek, \& M. Dvořáková (Eds.), Třetí věk trojí optikou (s. 71-88). Univerzita Palackého v Olomouci. 
Vale-Taylor, P. (2009). "We will remember them": a mixed-method study to explore which post-funeral remembrance activities are most significant and important to bereaved people living with loss, and why those particular activities are chosen. Palliative Medicine, 23(6), 537-544. https://doi.org/10.1177/0269216309103803

Vickio, C. J. (1999). Together in spirit: Keeping our relationships alive when loved ones die. Death Studies, 23(2), 161-175. https://doi.org/10.1080/074811899201127

Worden, J. W. (2009). Grief Counseling and Grief Therapy: A Handbook for the Mental Health Practitioner (4th ed). Springer.

Wright, S. T., Kerr, CH. W., Doroszczuk, N. M., Kuszczak, S. M., Hang, P. C., \& Luczkiewicz, D. L. (2014). The impact of dreams of the deceased on bereavement: A survey of hospice caregivers. American Journal of Hospice \& Palliative Medicine, 31(2), 132-138. https://doi.org/10.1177/1049909113479201

\section{Údaje o autorkách}

Bc. Miriam Masaryková je študentkou magisterského štúdia jednoodborovej psychológie na Katedre psychológie Trnavskej univerzity v Trnave. Zaujíma sa o problematiku smrti, straty a smútenia.

\section{Kontaktné údaje}

Adresa: Katedra psychológie, Filozofická fakulta, Trnavská univerzita v Trnave, Hornopotočná 23, 91843 Trnava

Email: miriam.masarykova1@gmail.com

Mgr. Lucia Záhorcová, PhD. je odbornou asistentkou Katedry psychológie FF TU v Trnave, vedeckou pracovníčkou Ústavu experimentálnej psychológie CSPV SAV. Pracuje ako externý psychológ $\mathrm{v}$ detskom mobilnom hospici. $\mathrm{K}$ jej odborným záujmom patrí predovšetkým problematika odpustenia, životných strát a smútenia po strate blízkeho človeka.

\section{Kontaktné údaje}

Adresa: Katedra psychológie, Filozofická fakulta, Trnavská univerzita v Trnave, Hornopotočná 23, 91843 Trnava

Email: zahorcova.lucia@gmail.com

Masaryková, M., \& Záhorcová, L. (2020). Kvalitatívna analýza prežívania pokračujúcich väzieb k zosnulému partnerovi u žien v období staroby. E-psychologie, 14(4), 16-30.

https://doi.org/10.29364/epsy.382 